Prekariat - perspektywa katolickiej nauki społecznej, red. J. Mazur OSPPE, ks. Ł. Marczak, Kraków 2017 (Spotkania Naukowe Wykładowców Katolickiej Nauki Społecznej, XIII), s. 15-22.

DOI: http://dx.doi.org/10.15633/9788374385985.02

Piotr Jaroszyński

Katolicki Uniwersytet Lubelski Jana Pawła II

\title{
Prekaryzm: kilka uwag filozofa kultury
}

Słowo prekariat jest jednym ze współczesnych neologizmów, które zostało utworzone obok takich słów, jak cogitariat, digitariat, intelektuariat na drodze mechanicznego łączenia słów zaczerpniętych z języków klasycznych, czyli greki i łaciny. Moda taka pojawiła się już w XVI wieku, ale była czytelna, ponieważ w owych czasach już na średnim poziomie wykształcenia znane były języki klasyczne, natomiast dziś ze względu na brak ich znajomości wiele neologizmów jest po prostu niezrozumiałych.

W słowie angielskim (precariat) obecny jest rdzeń łaciński: precarius, od precari - proszący, błagalny, wyżebrany; dalsze znaczenie: niepewny, chwilowy, udzielony do odwołania ${ }^{1}$. Zamiast końcówki -us wstawiona zostaje końcówka -iat, tak jak w słowie "proletar-iat”, i mamy kolejne nowe słowo. Z kolei prekar-yzm powstaje jako rzeczownik przez dodanie końcówki -izm² ${ }^{2}$ A więc prekariat to rzeczownik utworzony od przymiotnika, a prekaryzm to rzeczownik utworzony od czasownika.

Co wnosi rzeczownik jako kategoria gramatyczna do interesującego nas zagadnienia prekariatu? Są dwa elementy, które warto

1 Słownik łacińsko-polski, red. M. Plezia, Warszawa 1974, t. IV, s. 281.

${ }^{2}$ Po francusku -isme, po łacinie -ismus, po grecku -ismós. Tworzenie rzeczowników z czasowników (czynność). The Oxford Dictionary of English Etymology, New York 1966, s. 487. Gdy coś nabiera trwałych cech: Khristianismós - praktyki chrześcijan; średniowieczne paganismus. 
wydobyć. Po pierwsze, forma rzeczownikowa ma sugerować, że jest taka rzecz jak prekariat. Ma tu miejsce wzmocnienie ontologiczne zjawiska prekariatu. A po drugie, nadanie pojęciu zawartemu w słowie rangi teorii, np. ewolucja - ewolucjonizm, sugeruje, że za tym kryje się jakaś teoria naukowa, w każdym razie jakiś system myślowy, racjonalny. Podobnie słowo „prekariat” może być podstawą do utworzenia jakiejś szerszej teorii lub ideologii, a nie tylko do wydobycia znaczenia słowa. Właśnie prekariat pretenduje do roli kategorii, która będzie stanowić podstawę dla teorii, a zwłaszcza ideologii. Aby to dostrzec, należy spojrzeć na problem prekariatu w perspektywie historyczno-kulturowej. Jest to problem funkcjonowania $\mathrm{w}$ danym społeczeństwie warstwy społecznej o bardzo niskim statusie.

\section{Etapy formowania się prekariatu}

Patrząc z perspektywy historyczno-kulturowej, możemy zaobserwować trzy fazy formowania takich właśnie warstw. Pierwsza faza to pojawienie się niewolnictwa, którego głównym źródłem była wojna. W większości społeczeństw to właśnie wojna dostarczała niewolnika. Stawał się nim przeciwnik, który został pokonany. Mógł zostać zabity już w czasie walki, ale mógł też przeżyć. Za karę jednak lub dla korzyści zwycięzcy przeciwnik taki brany był do niewoli, ponieważ wypuszczenie go mogło być niebezpieczne. Jako niewolnik musiał wykonywać prace zlecone mu przez właściciela ${ }^{3}$. W rzeczywistości więc niewolnik nie był podmiotem tego społeczeństwa czy państwa, w którym się znalazł. $\mathrm{W}$ imperium rzymskim niewolnik nie był podmiotem, ale rzeczą, którą jego właściciel mógł swobodnie dysponować ${ }^{4}$. Zdarzały się bunty niewolników, w tym najsłynniejsze pod wodzą Spartakusa,

3 D. B. Davies, The Problem of Slavery in Western Culture, Ithaca, NY, 1966.

${ }^{4}$ W. Rozwadowski, Prawo rzymskie, Warszawa 1991, s. 247. 
ale z góry skazane były na niepowodzenie w konfrontacji z regularną armią państwową.

Druga faza, w której wyłoniła się najsłabsza warstwa społeczna, związana jest z wykształceniem się klasy robotników, którzy już posiadają określone prawa. Wskutek trudnych warunków bytowych opuszczają oni swoje rodzinne i zabiedzone wioski, by szukać pracy w mieście, w fabrykach, które powstają dzięki rewolucji przemysłowej (XIX wiek). Tę warstwę nazywano proletariatem, co było jednak uproszczeniem ideologicznym. Słowo proletariat pochodziło z łaciny i oznaczało rodziny biedne, ale wielodzietne (proles - dzieci) $)^{5}$. Tymczasem ideologia marksistowska „ochrzciła” robotników mianem proletariatu nie dlatego, że żyjąc w miastach, posiadają duże rodziny, lecz dlatego że są wyalienowanym środowiskiem ludzi biednych i zapracowanych. W takim ujęciu proletariat to robotnicy zatrudnieni $\mathrm{w}$ wielkim przemyśle. Robotnicy $\mathrm{z}$ jednej strony stopniowo organizują się w związki zawodowe, a $\mathrm{z}$ drugiej strony są poddawani oddziaływaniu partii politycznych.

A wreszcie trzecia faza, gdy pojawia się proletariat w wymiarze globalnym (XX wiek), gdy procesy globalizacyjne generują masy ludzkie pozbawione oparcia w rodzinie, państwie i religii. Są to masy potężne, ale niezorganizowane. I to jest właśnie prekariat. Zwraca się uwagę, że prekariat to ludzie pozostający w stanie niepewności z tytułu braku: własności (zwłaszcza środków produkcji), stałego zatrudnienia, udziału w podziale dochodu narodowego. Ta niepewność przeradza się w stan poczucia permanentnego zagrożenia i zachwianie poczucia własnej tożsamości.

\section{Uwarunkowania kultury protestancko-liberalnej}

Pojawia się zasadnicze pytanie: Skąd bierze się zjawisko prekariatu? Czy nie można po prostu dać wszystkim chętnym pracę? Problem

\footnotetext{
5 The Oxford Dictionary..., dz. cyt., s. 714.
} 
jest bardziej złożony. Aby zrozumieć zjawisko prekariatu, musimy najpierw cofnąć się do systemu ekonomicznego, zwanego kapitalizmem. System ten miał swoje oparcie ideowe w protestantyzmie i liberalnej filozofii brytyjskiej. Protestantyzm, w jednej ze swych odmian, dzielił ludzi na biednych i bogatych ze względu na predestynację i determinizm, czyli wolę Boga. To Bóg chce, aby jedni byli bogaci, a drudzy biedni, aby jedni byli wybrani, a inni opuszczeni ${ }^{6}$. W efekcie ludzie wierzący w ramach protestantyzmu, chcąc nie chcąc, musieli być ulegli takiemu rozstrzygnięciu, co odbiło się w końcu na pogłębiającej się biedzie szerokich mas proletariatu wielkomiejskiego. $\mathrm{Z}$ drugiej strony, nie można zapomnieć, że etyka liberalizmu była etyką egoistyczną, albowiem za podstawę ludzkich pragnień uznała egoizm. Ten egoizm został filozoficznie usankcjonowany. Wobec tego sam w sobie nie był czymś złym, lecz czymś naturalnym. Jednak w wymiarze społecznym prowadził nieuchronnie do walki wszystkich ze wszystkimi, co wyrażała łacińska formuła: „homo homini lupus est”. Należało więc go okiełznać w ramach państwa za pomocą umowy społecznej i stanowionego prawa ${ }^{7}$. Ale i tak egoizm pozostawał główną sprężyną ludzkich działań i wyborów. W ten sposób kultura protestancko-liberalna wypracowała typ biznesmena, który robi biznes z uwagi na swoją korzyść, niezależnie od moralności, ale zgodnie ze stanowionym prawem. Ponieważ istota biznesu polega na tym, aby zyski były coraz większe, więc wszystko to, co proces powiększania zysku zatrzymuje lub zysk zmniejsza, stanowi dla biznesu zagrożenie. Takim zagrożeniem mogą się stać sami pracownicy, których praca jako towar może w pewnych okolicznościach biznesmenom się nie opłacać. Stąd właśnie biorą się masowe zwolnienia, w których bierze się pod uwagę wartość pracy jako towaru,

\footnotetext{
${ }^{6}$ M. Weber, Etyka protestancka a duch kapitalizmu, tł. J. Miziński, Lublin 1994.

7 Th. Hobbes, Lewiatan, czyli materia, forma i władza państwa kościelnego $i$ świeckiego, tł. Cz. Znamierowski, Warszawa 1954, II, 17.
} 
a nie to, kto i po co pracuje jako pracownik, i czy zwolnienie zaszkodzi jemu i jego rodzinie.

System kapitalistyczny zaczął się stopniowo przekształcać z systemu państwowego w system globalny. Pociągnęło to za sobą negatywne skutki dla kapitalizmu i spowodowało pojawienie się nowych zagrożeń, gdy skala prowadzenia biznesu przekroczyła granice państw i kontynentów, nabierając wymiaru globalnego. Bezrobotny proletariat miejscowy stał się proletariatem globalnym, czyli prekariatem.

\section{Lokalny proletariat versus globalny prekariat}

Jakie byłyby zasadnicze różnice między proletariatem a prekariatem? Dawny proletariat wywodził się w znacznej części ze środowiska wiejskiego, w którym silne były związki rodzinne i sąsiedzkie. Dominowały rodziny wielodzietne i wielopokoleniowe, pielęgnujące od pokoleń tradycje lokalnej kultury i zachowujące obyczaje i wartości religijne. Ten proletariat, mimo że wyrwany ze swego wiejskiego środowiska, miał jednak zaplecze względnie zwartej i trwałej kultury. Nie od razu więc ulegał alienacji. Miał także szansę powrotu w rodzinne strony, gdyby sprzyjały temu warunki ekonomiczne, jakie mogły stać się udziałem posiadających zatrudnienie. Za ocean „za chlebem” mogły wyjeżdżać nie tylko całe rodziny, ale wręcz całe wioski. To pozwalało na zachowanie w zupełnie nowym miejscu, i to przez kilka pokoleń, własnego środowiska i własnej kultury. Były też wyjazdy indywidualne, podejmowane z myślą o rodzinie, która pozostała w kraju, by zaoszczędzone fundusze mogły ułatwić nie tylko przeżycie, ale inwestycję w zakup ziemi, budowę domu lub unowocześnienie całego gospodarstwa. Proletariusz ani nie niszczył swoich związków ze środowiskiem, z którego się wywodził, ani też nie porzucał idei powrotu do miejsca, $\mathrm{z}$ którym jego rodzina była związana od pokoleń. 
Natomiast prekariat wnosi jakby nową jakość: dokonuje się wielostronny proces alienacji, z którego wyjściem nie jest powrót do starego, ale budowa nowego miejsca na ziemi, najczęściej trudna do realizacji. Prekariusz odcina się od rodziny i miejsca, z którego pochodzi, w celu podjęcia budowy nowego miejsca i nowego środowiska. Tu jednak, choćby na poziomie małżeństwa, które jest osią wspólnoty, może się pojawić różnica środowiska lokalnego i narodowego, różnica wiary i obyczajów, które dają o sobie znać szczególnie w kolejnych pokoleniach. Nakłada się na to gotowość do mobilności w wymiarze krajowym, międzynarodowym, międzykontynentalnym, czyli globalnym. Dla prekariusza warunkiem przetrwania jest posiadanie pracy, gdziekolwiek ona jest. To wiąże się z naruszeniem stabilności potrzebnej do zawiązania się rodziny, utrzymania znajomości i przyjaźni, odnalezienia się w środowisku narodowym i religijnym. Budowa nowego środowiska jest praktycznie niemożliwa do urzeczywistnienia. I tak właśnie z proletariatu rodzi się prekariat z jego różnymi obliczami alienacji.

Praca prekariatu jest oderwana od podmiotu - człowieka i od celu życia człowieka w wymiarze społecznym, a więc rodzinnym, narodowym i religijnym. Prekariat nie tylko stanowi problem społeczny, ekonomiczny czy polityczny, ale przede wszystkim jest problemem cywilizacyjnym. Cywilizacja w tym wypadku oznacza całość i stałość punktów odniesienia (wartości i zasad), jakich człowiek potrzebuje do normalnego życia i rozwoju, a które odnaleźć może tylko w społeczeństwie, ale nie jakimkolwiek, lecz bliskim swoim przekonaniom. Obejmują one wszystkie dziedziny kultury, takie jak poznanie prawdy (edukacja i nauka), wychowanie do moralności (etyka), posiadanie własnej wspólnoty w mniejszych i większych kręgach, twórczość i piękno, wiara i religia. Te odniesienia muszą tworzyć względnie koherentną całość, aby człowiek mógł się rozwijać jako człowiek, a nie tylko jako pracownik czy wręcz handlarz wystawiający swoją pracę na sprzedaż jako towar.

W ramach wczesnego kapitalizmu, ze względu na jego stosunkowo niewielki zasięg i trwałość związków środowiskowych zawie- 
rających niezbędne komponenty cywilizacyjne, pracownik mógł się ciągle uczłowieczać, łącznie z zachowaniem eschatologicznej perspektywy swojego życia w wymiarze duchowym. W przypadku prekariatu zakres oddziaływania nowego systemu ekonomicznego jest globalny, co grozi zerwaniem wielu związków o znaczeniu cywilizacyjnym, prowadzącym do kulturowego chaosu i osobowego zubożenia.

Człowiek w perspektywie globalnego świata może pokonywać fizycznie czas i przestrzeń w większym wymiarze, aniżeli osadzić się $\mathrm{w}$ danej przestrzeni i $\mathrm{w}$ danym czasie w sposób integralny i organiczny, czyli taki, który pozwala mu na otwarcie się i czerpanie wartości stanowiących niezbędny składnik przetrwania i rozwoju. A gdy podstawowym środowiskiem jest rodzina, to ten proces czasoprzestrzennej akomodacji może przebiegać nie tylko w różnych segmentach czasowych, ale również z różnym stopniem intensywności. Szczególnie ciężko okres adaptacji w nowym środowisku przechodzą ludzie młodsi, zwłaszcza dzieci. Jeśli do tego dochodzi rozłąka, to proces integralnego dorastania może być istotnie zaburzony.

\section{Perspektywa religijna propozycją przezwyciężenia prekaryzmu}

Czy jest jakieś wyjście z tej dramatycznej sytuacji, w jakiej znajduje się prekariat? Wydaje się, że najsilniejszą formą rekompensaty i przywracania równowagi psychicznej i duchowej, rodzinnej i narodowej, jest religia. Doświadczenia polskich emigrantów ukazują, jak bardzo życie religijne, przybierając postać życia parafialnego, staje się substytutem innych form życia społecznego „wśród swoich”, form, które wskutek globalnych migracji ulegają znacznemu osłabieniu lub nawet są utracone, ale które dzięki religii mogą się odradzać.

Jest jasne, że prekariat pozbawiony religii i wspólnotowych form życia religijnego znajduje się w bardzo trudnej sytuacji nie 
tylko z punktu widzenia ekonomicznego, ale właśnie cywilizacyjnego i religijnego. Religia jest początkiem i kresem cywilizowania człowieka. Bez religii, która przecież w stopniu najwyższym wprowadza porządek w ludzkie życie - obejmuje bowiem początek i kres, środki i cele - cywilizacja nie tylko popada w stan chaosu, ale może również zwracać się przeciwko człowiekowi.

Religia pozwala na ukazanie zagrożeń, jakie płyną od globalizmu, gdy ten poprzez ekonomizm promuje redukcjonistyczną wizję człowieka, a przez ideologizację prowadzi do sekularyzmu, odbierając człowiekowi transcendentną perspektywę życia.

\section{Zakończenie}

Podsumowując, można stwierdzić, że badanie zjawiska prekaryzmu i szukanie dróg wyjścia nie może skupić się tylko na stronie ekonomicznej czy politycznej, lecz musi uwzględnić stronę cywilizacyjną i religijną, zarówno w sensie pozytywnym, jak i negatywnym. Są bowiem cywilizacje, którym prekaryzm sprzyja. Są także religie, które wzmacniają prekaryzm, ale są i takie, które pomagają odnaleźć się człowiekowi jako osobie obdarzonej godnością, a dla których sytuacja prekariusza jest sytuacją upokarzającą. Właśnie dlatego warto zadać pytanie o obraz człowieka w danym systemie ekonomicznym i politycznym, religijnym i cywilizacyjnym. Wtedy bowiem można lepiej rozumieć i skuteczniej przeciwdziałać temu, co stanowi zagrożenie dla godności człowieka jako osoby. 